\title{
The Arabic Sea Battle: al-Fārābī on the Problem of Future Contingents
}

\author{
by Peter Adamson (London)
}

\begin{abstract}
Ancient commentators like Ammonius and Boethius tried to solve Aristotle's "sea battle argument" in On Interpretation 9 by saying that statements about future contingents are "indefinitely" true or false. They were followed by al-Fārābī in his commentary on On Interpretation. The article sets out two possible interpretations of what "indefinitely" means here, and shows that al-Fārābī actually has both conceptions: one applied in his interpretation of Aristotle, and another that he is forced into by the problem of divine foreknowledge. It also explains the relevance of al-Fārābī's remarks as a link between the non-statistical modal theories of Philo and Avicenna.
\end{abstract}

Few passages in the Aristotelian corpus have provoked such intense commentary and scrutiny as the ninth chapter of On Interpretation, in which Aristotle presents an argument for determinism using the famous example of a sea battle. Roughly, the problem is this: if it is true now that there will be a sea battle tomorrow, then it is already "settled" that the sea battle will occur tomorrow. Thus it is necessary that there be a sea battle. Since the same line of reasoning may be applied to any event, everything that happens, happens necessarily. The tradition of commentary on this argument begins at least as early as the school of Alexander of Aphrodisias, and the late ancient interpretation of Aristotle's text has now itself become the subject of a substantial body of secondary literature. ${ }^{1}$ Disagreements about the interpretations given by the commentators reflect disagreements about Aristotle's original discussion, because scholars working on Aristotle have been keen to find in the commentators a precedent for their own preferred interpretations of De int 9 . The present paper concentrates on a treatment of the text that comes still later in the tradition: that found in a commentary on $\mathrm{On}$

\footnotetext{
1 For Alexander's school see Sharples 1982. For later Neoplatonic treatments, see Sorabji 1980, 91-103; Frede 1985, 42ff.; Gaskin 1995; Ammonius / Boethius 1998, with interpretive essays by Sorabji, Kretzmann and Mignucci; and Seel 2001, with interpretive essays by Seel and Mignucci (Mignucci's contribution to this volume is a revision of the essay from Ammonius / Boethius 1998).
}

Archiv f. Gesch. d. Philosophie 88. Bd., S. 163-188 DOI 10.1515/AGPH.2006.007 (C) Walter de Gruyter 2006

ISSN 0003-9101 
Interpretation by the tenth century philosopher al-Fārābī. ${ }^{2}$ His commentary is a striking example of the continuity of late Greek and early Arabic philosophy: the section on De int 9 repeats, sometimes verbatim, passages and interpretations still extant in the commentaries of Ammonius and Boethius. ${ }^{3}$

In what follows we will be largely preoccupied with two ways of understanding the solution to the sea battle problem given by the ancient commentators. It is uncontroversial that, like most modern interpreters, they see Aristotle as presenting a deterministic argument that proceeds from the Principle of Bivalence (PB), which is that any meaningful assertoric statement $P$ is either true or false (this is equivalent to saying that either $P$ or its antithesis Not- $P$ is true). A statement about the future, e.g. "there will be a sea battle tomorrow", is then substituted for $P$. How the argument is supposed to work from that point onwards is disputed. Some modern readers think that Aristotle's determinist makes an illegitimate inference from Necessarily: $P$ or Not-P to Necessarily: P or Necessarily: Not-P. Others think the determinist is just supposing that truth implies necessity: if $P$ then Nec $P$ - and further that Aristotle may accept this supposition, a suspicion whose initial implausibility is diminished by the observation that, for Aristotle, present

2 Which has been translated, with extensive commentary, in Zimmermann 1981. The Arabic edition for the commentary is in Kutsch and Marrow 1960, hereafter referred to simply as Commentary. The text reproduces quite faithfully a faulty manuscript, so numerous corrections are needed; I have adopted the readings given in the notes of Zimmermann's translation unless otherwise noted. The Treatise, a short paraphrase of De int, which I shall also discuss in passing below, is edited in Küyel-Türker 1966.

3 For Ammonius' commentary see $C A G$ IV.5, A. Busse (ed.), reprinted in Seel 2001. For Boethius' see Boethius 1877. The relevant sections of both are translated in Ammonius / Boethius 1998. Zimmermann 1981 detects two separate archetypes here, and says that there is influence on al-Fārābi from both strands of the commentary tradition. But he points out several features of his discussion of ch. 9 that seem to relate more to the Boethian archetype (see his page xcv), which in his view preserves more of the discussion of Alexander of Aphrodisias, probably by way of Porphyry. However there seem to me signs in this section of dependence on the Ammonian archetype as well: for example, Ammonius 151.34-152.11 looks as if it stands behind Commentary 97.7-15, especially the last sentence in each case. And as we will see below, al-Fārābī's criticism of the "commentators" in regard to their analysis of Aristotle's procedure in ch. 9 is directed at the sort of approach we find in Ammonius but not in Boethius. Two other ancient commentaries are close to Ammonius: an anonymous commentary and that of Stephanus. For the latter see Stephanus 2000. For the anonymous commentary see Tarán 1978. 
and past states of affairs obtain necessarily. In that case, since PB says that either $P$ or Not- $P$ is now true, the necessity of the true antithesis will follow.

However it is construed, the ancient commentators believe that Aristotle hoped to escape from the argument by admitting that antitheses regarding future contingents are indeed either true or false - so PB, in their view, does apply to statements regarding future contingents - but then saying that the antitheses are not "definitely" true or false

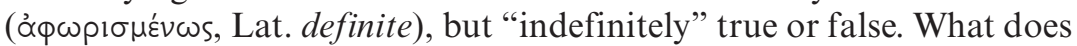
this mean? There are two possibilities, both of which have found their adherents in recent literature. For the sake of brevity I shall call them (A) and (B):

(A) Neither statement is (yet) true, or false, but each antithesis is either-true-or-false. In other words, the truth values are not (yet) distributed between $P$ and Not-P. This corresponds roughly to, and is often thought to be equivalent to, what has been called the "Standard" or "Traditional" interpretation, which holds that Aristotle simply denies $\mathrm{PB}$ in the case of statements about future contingents. ${ }^{4}$

(B) It is now the case that either $P$ or Not-P is true, in the sense that the truth value is already distributed. However, it is distributed in an "indefinite" way, which means not that the truth is as it were "hovering" between the two antitheses, as (A) would have it, but rather that the true statement is true in a way appropriate to contingent facts, events, or states of affairs. This corresponds to a popular "Non-Standard" interpretation ${ }^{5}$, which holds that Aristotle is willing to admit that if $P$ is now true, the event predicted by $P$ will in fact take place. But, he will insist, things might nevertheless have been otherwise: $P$ does not imply anything's occurring necessarily, but rather its occurring contingently. ${ }^{6}$

4 This reading of some or all the ancient commentators has been defended most prominently by Frede, Gaskin, and Kretzmann. They all admit that (A) is equivalent to a denial of PB except in its "rhetoric", since PB as we understand it says that $P$ is either true or false, not either-true-or-false. However, as Gaskin says this rhetorical difference is a pivotal one, since it allows them to insist that actually Aristotle does accept PB (in an admittedly modified form) for all assertoric statements.

5 First put forward in the modern literature by Anscombe 1956, revised version in Moravcsik 1968, 15-33.

6 This interpretation of the commentators has been defended prominently by Sorabji, Mignucci, and Seel. I do not here distinguish between the version of (B) on which "indefinitely true" means nothing more than "contingently true", and the slightly more complicated version of (B) put forward by Mignucci. The points given below for and against finding (B) in al-Fārābī would, I think, all be valid on either of these versions of (B). 
One clear way of putting the difference between (A) and (B) is that, according to (B), a single statement (one half of an antithetical pair) can be "indefinitely true" or "indefinitely false", but not both. For (A) by contrast, if $P$ is "indefinitely true" this implies that it is also "indefinitely false" , and hence that Not-P is likewise both indefinitely true and indefinitely false.

There has been as yet no full discussion of which of these interpretations is to be found in al-Fārābī, taking in the evidence of the entire text. Indeed there is some confusion in the literature as to al-Fārābỉ's position. This is largely the result of Nicholas Rescher's announcement that al-Fārābi was the inventor of the "Non-Standard" interpretation described under (B) above, which he calls the "Farabian" interpretation. ${ }^{8}$ In the introduction to his translation of al-Fārābì's commentary, Fritz Zimmermann stated that this was a "manifest error" on Rescher's part, and that in fact al-Fārābī followed the ancient commentators in holding that statements about the future are "indefinite" in sense (A) above. ${ }^{9}$ In what follows I will suggest that in a sense Rescher and Zimmermann are both right, because al-Fārābī has not one, but two solutions to the sea battle. The first solution, which he gives in his comments on the actual lemmata of On Interpretation, is in accordance with (A). But a second solution, which accords with (B), is then given in response to the additional problem of divine foreknowledge. ${ }^{10}$ The historical implications of both solutions are significant. Al-Fārābi's adoption of (A) in the commentary proper is evidence relevant to our understanding of the ancient commentators. ${ }^{11}$ And as we will

7 As pointed out by Gaskin 1995, 155.

8 See Rescher 1963.

9 Zimmermann 1981, 79, followed by Gaskin 1995, 329-330. Talanga 1981, 307 remarks "Man kann zusammen mit Zimmermann mit Fug und Recht behaupten, daß sich die 'farabische' Interpretation bei al-Fārābī nicht finden läßt".

${ }^{10}$ It must be said that Zimmermann and Gaskin come out of the disagreement somewhat better than Rescher. For one thing, if, as I argue, he was correct to find (B) in al-Fārābī, he was wrong to think that al-Fārābī puts it forward as an interpretation of Aristotle. For another thing it is far from clear that (B) was never put forward prior to al-Fārābì. It is also not clear on what basis Rescher ascribes (B) to al-Fārābī, though he may have al-Fārābī's second solution in mind given his allusion to divine foreknowledge at $45 \mathrm{f}$. Gaskin is one of very few commentators to appreciate the importance of the distinction between the first and second solution: he says at 330 that al-Fārābī offers (A) as an interpretation of Aristotle but (B) "in propria voce".

11 I would caution the reader, though, against reading too much into his acceptance of (A) as the correct understanding of what "indefinitely true" means. Al-Fārābī 
see, his presentation of a solution like the one (B) would find in De int 9 anticipates the conception of modality we find in Ibn Sīnā. Before plunging into our analysis of al-Fārābī's solutions, though, I want to draw attention to another underappreciated aspect of his commentary on ch. 9, namely his claim about the procedure here employed by Aristotle. ${ }^{12}$

\section{A Methodological Observation}

It is standard in discussions of De int 9 to present Aristotle as offering us a dilemma. On the one hand, PB is a bedrock principle of Aristotelian logic, and as stated above holds for any assertoric statement. On the other, we have a strong intuition that some events, particularly those involving our own choices, are contingent. The determinist argument of De int 9 is then supposed to show that we must abandon one of these two commitments. Depending on our interpretation, Aristotle responds either by grasping the first horn of the dilemma and restricting PB so as not to apply to statements about future contingents (as (A) would have it), or by diagnosing the determinist's argument as sophistical ((B) is one of several such readings). Either way, Aristotle is trying

may have been closer in time to the commentators than we are, but his access to their discussions was certainly worse: for one thing, it would seem that he worked only with sometimes garbled Arabic versions of Aristotle and the commentaries, whereas we have the Greek. So those who want to see the Greek and Latin commentators as holding (B) should not despair to learn that al-Fārābì disagreed with them.

12 In addition to the works already cited, there are a few other studies of al-Fārābīs treatment of De int 9. The most significant is Baffioni / Nasti de Vincentis 1981, which includes an Italian translation and commentary by Baffioni and further discussion by de Vincentis. There is an English translation with short introduction in Gyeke 1977. The text is discussed in Zaroug 1972, and in Marmura 1985 (see in the same volume the response in Kogan 1985). With regard to the two solutions (A) and (B), Marmura seems to concentrate on the second solution and hence to ascribe (B) to al-Fārābī, though he tries to tie this (at 83) to the question of whether the event that is predicted is causally determined, which does not seem to me to arise in the context of al-Fārābī's discussion (see below for this distinction). Zaroug does not distinguish between the two solutions or between (A) and (B). In Baffioni / de Vincentis 1981, the contribution by de Vincentis argues against Rescher's attribution of solution (B) to al-Fārābī. There is, finally, a general discussion of the medieval reception of De int in Black 1991; al-Fārābī's commentary is discussed at $48 \mathrm{ff}$., though Black does not here discuss the sea battle problem in detail. 
to find a way out of a dilemma that threatens the reality of contingency and hence free will. ${ }^{13}$

Al-Fārābi is emphatic that this way of understanding Aristotle's procedure is mistaken. The reason it is mistaken is that it invites us to see contingency as threatened by the argument. But, according to al-Fā-

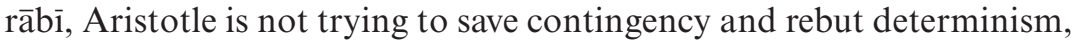
rather he is assuming from the outset that determinism is false. He thus sees the chapter as having the structure, not of a dilemma, but of a reductio: a certain view about the status of statements about the future leads to determinism; therefore, because we know for certain that some things are contingent, that view is wrong (see Commentary 84.6-10). Al-Fārābì takes the "commentators" to task for not understanding this (84.10-16). For it would follow from their dilemmatic analysis of the text that we are here, in a treatise on logic, attempting to determine the metaphysical status of contingency: logic would then determine, "regarding the natures of things that exist, how they exist". But the commentators themselves, when they discuss the Categories, reject this procedure.

Al-Fārābī's polemic against the commentators' dilemmatic analysis of the chapter is important in several respects ${ }^{14}$. Firstly, he is not wrong in ascribing this analysis to the commentators: it is found in Ammonius. Ammonius explains in the course of his commentary why the sea battle problem is relevant to all parts of philosophy. In logic, as well as in ethics, physics and first philosophy (i.e. theology), one must "investigate whether all that comes to be arises of necessity or whether some things arise from chance and spontaneously" (130.36-131.1) - though in ethics one must

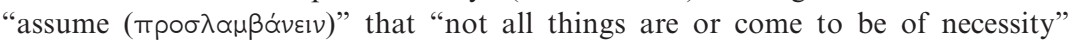

13 Kretzmann states this view particularly clearly in Ammonius / Boethius 1998, 24 : "Aristotle is faced with a dilemma: he must either accept determinism with its radically counter-intuitive implications or deny what had appeared to him to be the essential nature of propositions". A sampling of others with diverse interpretations who nevertheless agree, at least implicitly, with this reading: Hintikka 1973, 153, says that De int 9 presents a dilemmatic aporia; Waterlow 1982, 84 speaks of Aristotle aiming to provide a "defence of human agency" via a defense of contingency; Bäck 1992, 139, says that in De int 9 "Aristotle seeks to save chance"; Seel 2001, 17, presents the chapter as showing the inconsistency of a set of logical principles with the belief in contingency.

14 Here I disagree to some extent with Zimmermann 1981, cviii-cix, who praises alFārābi for the "acute observation" that the chapter has the form of a reductio, but doubts whether any of the ancient commentators used the approach here criticized, and adds, "in view of the fact that al-Fārābī embraces a thoroughly traditional interpretation of the chapter, transmitted no doubt by the very commentators he criticizes, his criticism would seem churlish and pedantic. It amounts to no more than a correction of emphasis". 
$(130.29-30)^{15}$. Later (147.27-148.5), Ammonius seems to gesture in the direction of al-Fārābì's understanding of the chapter as a reductio, when he says that Aristotle calls the consequences of determinism "'absurdities', although he has not yet shown

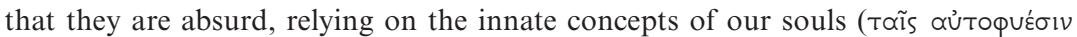

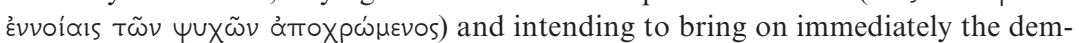
onstration of the absurdity of the argument that attempts to destroy the contingent". But then he adds:

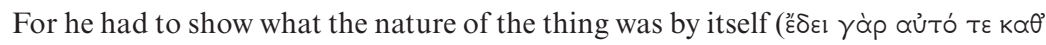

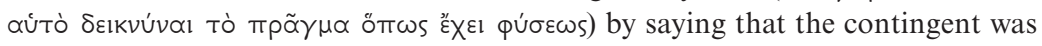
among the things that exist (since many impossible things follow for those seeking

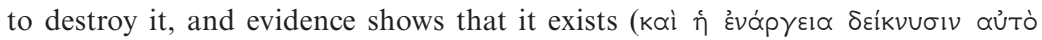

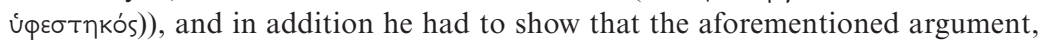
which tried to make everything necessary and to expel the contingent from the things that exist, was unsound. ${ }^{16}$

Thus Ammonius sees the chapter as an attempt to refute an argument against contingency, rather than as an appeal to contingency to settle a dispute within logic. And he explicitly says that De int 9 is an inquiry into the nature and existence of the contingent, and that the discussion is important for metaphysics. He goes beyond the concerns of logic, as al-Fārābī complains. Interestingly, though, our other most important ancient commentary on the chapter, that of Boethius, agrees with al-Fārābī. Boethius gives a "syllogism" summarizing the chapter's structure, which is a reductio that begins from the claim that all affirmations have definite truth values, and ends in the absurd consequence that determinism is true. ${ }^{17}$ This may be original with Boethius; in any case it may be that al-Fārābi knew only of Greek sources that gave the dilemmatic interpretation. ${ }^{18}$

A second point to note here is al-Fārābī's confidence in claiming certain knowledge that some things are contingent. It is not the logical status of statements that is "known in itself, with a primary, evident knowledge (ma'lüman bi-nafsihì bi-ilm awwal bayyin) that involves no doubt" (83.11). Rather, it is the reality of contingency that is known to us "from the very beginning and through what is innate to us (fitarina $\bar{a})$ " (83.13-14). Contingency, furthermore, is grasped primarily through our immediate awareness that we possess a power of "choice and volition (ikhtiyār, irāda)" (83.15). We must "posit it among the selfevident premisses (al-muqaddamāt al-bayyina bi-anfusihā) and principles" (84.5). All of this is expressed in terminology reminiscent of other Farabian works, for example the beginning of the Attainment of

15 He is followed in this by Stephanus 2000, 153.

16 The translation of these passages is from Ammonius / Boethius 1998.

17 See Ammonius / Boethius 1998, 134.

18 Although he does speak at 83.8 only of "most commentators (jull al-mufassirinn)". 
Happiness: "The theoretical virtues are those kinds of knowledge (al'ulüm) whose ultimate objective is to bring it about that the existents and whatever they embrace are intelligible with certainty, and nothing else. Some of these kinds of knowledge are attained by man from the outset [...]. These are the primary sorts of knowledge (al-iulum alawwal) [...]. Things known by primary knowledge are the primary premises (al-muqaddamāt al-awwal), and from them one comes to further knowledge, which is reached by investigation, discovery, teaching, and learning" 19 .

The vividness of al-Fārābī's rhetoric in this section is directed not so much against the misleading interpretation of the commentators, but rather the denial of contingency and freedom on the part of some of his own contemporaries. These are people who, ignoring their innate instinct (fitra), invoke tradition, the Law and authority (wad ${ }^{c}$, $\left.\operatorname{shari}^{-} a, q a w l\right)$ to insist that contingency does not exist, and thus that humans have no power of choice. As Zimmermann has pointed out ${ }^{20}$, the targets of this diatribe are bound to be mutakallimūn, such as Jahm b. Safwān, who denied human free choice. Against them al-Fārābī insists, more stridently than elsewhere but still consistently with his other works ${ }^{21}$, that our belief in human freedom is not threatened by any argument for determinism. Indeed, it is impossible that it be so threatened, because we accept the existence of contingency as an immediate first principle. Thus there are no considerations that could, even in theory, induce rational doubt about it.

It is worth noting in this regard that al-Fārābi conflates two sorts of determinism in his zeal to chastize his opponents. The sort of determinism relevant to De int 9 is logical determinism, whereas the determinism of al-Fārābīs contemporaries would normally have been causal determinism, embraced in order to safeguard divine omnipotence - hence the debate about whether the "power (qudra)" for human actions in fact lies with God. ${ }^{22}$ Both sorts of determinism hold that everything

19 Al-Fārābī 1926, 2. For an English translation of this work see Mahdi 1962.

20 Zimmermann 1981, cxiii-cxviii.

21 For example he insists that voluntary actions proceeding from deliberation are immune to causal determination by the stars. On this see Druart 1981, 39-40.

22 The dispute over qudra begins within the first few hundred years of the advent of Islam: see for example Schwartz 1967. This question of causal determinism by God is rarely distinguished with any clarity from the question of whether God's foreknowledge implies determinism. For example al-Fārābī’s own student, Yahyā b. 'Adī, raises the deterministic argument that God knows all existents (mawjī$d \bar{a} t)$, and the state of His knowledge must be like the state of the objects of His knowledge, but the state of His knowledge is necessary (darūri $)$ and unchanging, so that what He knows must also be necessary and unchanging. This is an argument for logical determinism, but in refuting it he argues that divine foreknowledge does not necessitate our actions because it does not fall into any of the ac- 
happens necessarily, but causal determinism is compatible with the view that some or even all events are contingent in themselves, though they are made necessary by prior events or agents. ${ }^{23}$ Of course the sea battle problem and the solutions to it given by al-Fārābī deal only with logical determinism. Yet his claim that we have an innate awareness of freedom and thus of contingency is of course a relevant, though question-begging, response to either logical or causal determinism. This shows why he is so concerned to emphasize that Aristotle takes it for granted that determinism is false, and thus that the structure of the chapter is that of a reductio: it gives him an ally, in the shape of Aristotle no less, in his insistence that we all know immediately and without doubt that we have freedom.

This brings us back to De int 9 itself: what, if any, are the consequences of al-Fārābī's methodological point for his understanding of the chapter as a whole? For one thing, it shows that whatever is his solution to the sea battle, it ought not to be on an epistemic par with our intuition of contingency. It should not, that is, appeal directly to a first principle, because then the solution would be just as "obvious" as the reality of contingency, and not need to be established via the reductio. Al-Fārābi acknowledges this explicitly later on, when he is discussing whether to accept the notion of possibility and necessity set forth in his second solution. He says that this notion is not something "evident in itself (bayyin fi nafsihì)" (100.15-16), echoing the terminology of the earlier passage. The implication is clear: people might honestly and rationally disagree about the status of statements regarding future contingents, but not about whether contingency itself is real. Furthermore, al-Fārābì's analysis of the chapter's structure puts him firmly in the camp of those who think that determinism is a valid consequence that follows from asserting some logical principle, namely a strong version of PB that says that every statement is determinately true or false. He

cepted classes of cause. (To be fair to Ibn 'Adī, he says he is responding to opponents who have put the problem in this way: "they imagine that foreknowledge is a necessitating cause (sabab) for things", 67.10-11. He is then perhaps only responding to others who have confused logical with causal determinism.) This same treatise, Fì ithbāt țabī'a al-mumkin ("On the Nature of the Possible"), ends with a commentary on De int 9. See Ehrig-Eggert 1989, 66 in the Arabic pagination. For a translation of and commentary on the work, see Ehrig-Eggert 1990.

${ }^{23}$ I have recently argued that al-Fārābī's predecessor al-Kindī was a causal but not a logical determinist: see Adamson 2003, 66-75. Avicenna may have held the same view; see Ivry 1984. 
would have no truck with the suggestion that Aristotle is just trying to unmask a sophistry. Instead, he concentrates all his attention on rejecting the first premise, and claiming that PB holds for some statements only "indeterminately". It is to this claim, then, that we must now turn our own attention.

\section{The First Solution: P is only "indeterminately true or false"}

Al-Fārābì begins his treatment of De int 9 by characterizing Aristotle's program in the chapter as follows:

Commentary 81.9-12: Now Aristotle comes to the fourth task (amr) regarding antitheses, namely to consider the state $(h \bar{a} l)$ of antitheses in the three times [sc. past, present and future]. Of what sort is each of the antitheses' distribution (iqtisām) of the true and the false in each of the three times? Do each of them distribute [the

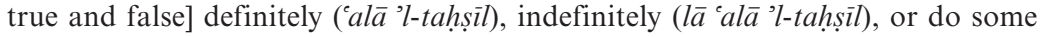
distribute definitely and some indefinitely?

Thus the question of what he means by "definitely" and "indefinitely" is a pressing matter from the very outset. To reiterate, there are two interpretations to be considered. On (A), he means that two antitheses distribute truth and falsity "indefinitely" if neither is yet true to the exclusion of the other, but both are either-true-or-false. On (B), he means they are indefinite if one of the two antitheses is true, and the other false, but they are respectively indefinitely true and indefinitely false. This means that the thing, event, or state of affairs to which they refer is contingent and not necessary.

It is natural to begin by looking at the terminology used to express this. The phrase 'ala 'l-tahsịl corresponds to ớw

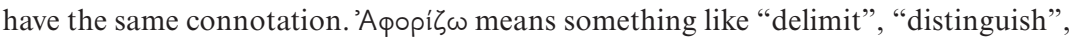
or "separate". Thus to say that future contingent antitheses fail to distribute truth and falsity å $\phi \omega \rho ı \mu \varepsilon \dot{v} \omega \omega s$ seems to be grist for the mill of interpretation (A): the two antitheses do not "separate" truth from falsity. ${ }^{24}$ As Marmura has remarked, "ala 'l-tahsîl could be translated literally "as 'by way of realization,' 'by way of obtainment,' or an equivalent of this, the idea conveyed being that of something completed and settled"25. Thus to say that something is true "indefinitely" (al-Fārābì uses the

24 As is pointed out by Gaskin 1995,150

25 Marmura 1985, 82. Baffioni, in Baffioni / de Vincentis 1981, 34f., suggests that the phrase could also have the epistemological sense of what we come to know (tahṣil can mean acquisition of knowledge); thus it has a "subjective", as well as an "objective" connotation. 


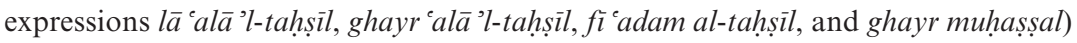
might naturally be taken to support (A): "definite" would mean that it is already "settled" that one antithesis is true to the exclusion of the other, and "indefinite" would mean that neither antithesis is yet true. However, if we consider the fact that for Aristotle and al-Fārābī, present and past events are necessary, then we could understand the phrase in accordance with (B) as well. For if events that have already "happened" (hașala) are thereby necessary, "alà 'l-tahșil could mean "established necessarily". Of course, we should not rely too much on the connotation of the Arabic phrase in arguing for either interpretation. The terminology was not original with al-Fārābī, but would have been present already in his Arabic version of De int. At most it guided his own reading of the philosophical issues, but he did not choose it in order to express that reading.

Let us turn instead, then, to al-Fārābī's use of the terminology, to see whether he gives us any clues as to how he took the phrase. Interpretation (B) seems to be strikingly confirmed by the following passage:

Commentary 82.21-25: Aristotle means that the situation of antitheses regarding [future contingents] is not that the true one of the two is true definitely (laysa 'l-șādiq min-humā șädiq 'ala 'l-tahșill), and the false one false definitely, either in itself or for us. [Aristotle means rather] that the state of the affirmative and negative antitheses about [future contingents] is like the state of the existence of [the future contingents]. Because their existence is indefinite, the truth of one of the antitheses is also indefinite (kāna ayḍan șidq aḥad al-mutaqābilayn ghayr muhasssal). Likewise, because the non-existence of the one of them that will not exist is indefinite ( $k \bar{a} n a$ la wujū ma $l \bar{a}$ yujadu min-hă ghayr muhașsal), the falsehood of one of the antitheses is indefinite, both in itself and for us.

Al-Fārābī seems to say here precisely what interpretation (B) requires, and interpretation (A) cannot allow: that of two antitheses regarding future contingents, one of them is true, and the other one is false. Nor is this an isolated example. For instance at one point he restates Aristotle's central question as follows (84.6-7): "regarding antitheses, is truth in one of the two and falsity in the other definitely, or not?" He answers: "for a pair of antitheses regarding possibles, the truth of the true antithesis (sidq al-șādiq min al-mutaqābilayn) is indefinite in itself" (84.9-10). This strongly suggests that al-Fārābì accepts, as (B) needs him to, that truth and falsity are indeed distributed between the two antitheses. The question is, "how is the true one true, definitely or indefinitely?" which already assumes that one of them is true to the exclusion of the other.

Interpretation (B) might also take encouragement from al-Fārābī's willingness to speak of things other than such antitheses as being "indefinite". He says that contingent things have indefinite "existence 
(wujūd)" (e.g. at 81.16-17, and in a passage just cited, at 82.23-24), and also that possible things have an indefinite "cause (sabab)" (86.26-28). The notion of indefinite existence is easy enough to understand on (B): something exists indefinitely if and only if it is contingent. Perhaps one might also make sense of "indefinite existence" on (A), by saying that what exists indefinitely does not yet either exist or not exist, just as a statement about the future is not yet either true or false, precisely because either could occur. ${ }^{26}$ "Indefinite cause" is a bit more difficult for (A), because al-Fārābī seems to equate it with an "accidental cause (sabab bi-arad)". It is natural to understand this as saying that an indefinite cause is a cause that is actual but that might not have obtained, i.e. a cause compatible with contingency, rather than as a cause that does not yet either obtain or not obtain. However, if al-Fārābi follows Aristotle in thinking that the past and present are necessary, as he seems to do at one point ${ }^{27}$, then it will be only future things that have such indefinite causes. This makes the latter reading, that an indefinite cause is one that does not yet obtain, more plausible.

In any case, these points in favor of (B) are overwhelmed by the evidence in favor of (A). An important piece of this evidence was already noted by Zimmermann: in the Treatise, al-Fārābī says that in the case of antitheses about the contingent, "it is not possible that truth be definite (muhassal) for one of the aforementioned and falsity for the other, such that it is impossible for the true one to be false and the false one to be true" 28 . Zimmermann took this as sufficient evidence for (A) and has been followed by Gaskin. ${ }^{29}$ There is room for doubt, though. Although it is striking that al-Fārābi denies specifically that truth attaches to one rather the other, just as he should on interpretation (A), he goes on to add, "in such a way as to make it impossible for the true one to be false". So supporters of (B) might argue that what al-Fārābī means is that neither antithesis can singly be true in a

26 Al-Fārābī speaks of the indefinite has having a "deficiency" or "lack" (nāqș) in its existence (e.g. at 97.22). This could be interpreted as being in harmony with either (A) or (B), it seems to me.

27 At 82.4-5 he says that the past and present things mentioned at De int 18a28ff. are subject to "definite" truth and falsity, which on either (A) or (B) implies necessity. The conception of modality deployed in the second solution would imply however that the present and past are not necessary.

28 Küyel-Türker 1966, 79.14-16. See Zimmermann 1981, 244-245.

29 Zimmermann 1981, lxviii; Gaskin 1995, 329-330. 
definite way, that is, in a way that would make the future event necessary. ${ }^{30}$

Turning to the Commentary, then, what is the case to be made for interpretation (A)? Let us first begin by returning to the use of the phrase "ala "l-tahsill to mean "definite". It is worth noting a passage where al-Fārābī says al-majhūl ghayr muhașṣal al-șidq fì 'l-nafsinā (very literally: "the unknown does not have truth occurring in our souls"). Here the same root $h-s+l$, indeed the same phrase al-Fārābi sometimes uses for "indefinite" (ghayr muhașal), is used to express the fact that what is "unknown (majhül)" to us is that to which we are unable to assign truth. If al-Fārābi thinks of the truth of an antithesis, rather than its subject-matter, as that which does not "occur" in the case of statements about future contingents, then (A) has to be the correct interpretation.

Second, let us consider the point that al-Fārābī often speaks of only one antithesis as being true. While this is a powerful argument for (B), indeed in my view the only strong evidence for (B), still al-Fārābī sometimes seems to use caution in avoiding the locution. One example is the aforementioned passage from the Treatise. Another is his first characterization of the definite and indefinite at 81.9-15, which is likely to be his most careful formulation. Here he speaks of the definite by saying that one antithesis is true, the other false, and that the truth of the true one is "distinguished (mutamayyiz)" from the falsity of the false one. When he comes to the indefinite, though, he says only that the antitheses are in an indefinite state, "both in themselves and in our souls" 31 , without suggesting that the true and false are distinguished.

30 Gaskin 1995, 330, admits that the use of the word "impossible" is, as he says, "unfortunate", insofar as al-Fārābì is entitled to a stronger claim, and that the phrase could give encouragement to supporters of (B) (which he calls " $\mathrm{R}$ " for "Realist"). He thinks that al-Fārābī's claim shortly thereafter (Zimmermann's 245), which reiterates that in the case of indefinite truth it is not the case "that this particular one is true rather than the other", confirms reading (A). However that is only in the context of a statement about our epistemic status regarding indefinites, so again the supporter of (B) might escape by supposing that al-Fārābi only means that we cannot say which is true and which is false, even though one is in fact (indefinitely) true and the other (indefinitely) false. Of course I argue here only as devil's advocate, since I agree with Gaskin's interpretation of these passages; but I believe that the interpretation requires support from the Commentary, which is in any case the more complex and significant treatment of these questions.

31 There is an untranslatable pun on nafs ("self" or "soul") in this last phrase here: "in themselves" is fi anfusiha $\bar{a}$, and "in our souls" is fi anfusina. 
Now, let us turn to the positive evidence for interpretation (A). First, consider the passage just mentioned, in which al-Fārābī says that antitheses about the future are indefinite "in our souls". This is one of numerous points at which al-Fārābi is careful to emphasize that the sea battle problem is not merely epistemic. That is, he consistently distin-

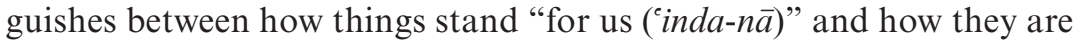
"in themselves", and points out that even in the case of necessary things we might be unable to know things definitely, even though they are definite in themselves. But on interpretation (B), what sense does it make for something to be "indefinite for us"? For (B), "indefinite" needs to mean "true, but compatible with contingency". But al-Fārābì clearly means that that which is indefinite to us is that of which we are ignorant; indeed he says so explicitly (97.16-17). So interpretation (B) would require that, in the passages where al-Fārābī speaks of antitheses being "indefinite in themselves and to us", "indefinite" is equivocal. "In itself" an indefinite antithesis would be true, and not false, but "for us" its being indefinite would mean precisely that it is neither true nor false (or, if you prefer, either-true-or-false, but not yet one or the other). ${ }^{32}$

Second, al-Fārābī seems to consider necessity to follow from truth, in the way described above (if $P$ then Nec P). A crucial step in the argument of ch. 9 is the passage where Aristotle says, in laying out the deterministic argument, "if every affirmation or negation is either true or false, then it is necessary that everything is existent or non-existent" (18a34-35, translated from the Arabic version). As we have already seen, al-Fārābì thinks that Aristotle's deterministic argument is a valid one, but proceeds from a faulty premise. So it is unsurprising that the move proposed by Aristotle at 18a34-35 is wholeheartedly endorsed by al-Fārābì: "this universal judgment is self-evidently correct" (Commentary 85.12). He then adds, "for from the true statement follows the thing (al-amr), and from the false statement follows the non-existence of the thing" (85.12-13). This inference from simple truth to necessity is disastrous for interpretation (B), the whole point of which is to say that "there will be a sea battle" can be true without the sea battle's occurring necessarily. The passage can only be reconciled with (B) by pointing out

32 In Boethius and Ammonius we similarly find use of "definite" or "indefinite" to refer to epistemic states (e.g. God's knowledge of the future must be "definite" whereas ours is "indefinite") and to modify the truth values of propositions. So the point with regard to al-Fārābì is equally applicable to these other commentators. 
that al-Fārābi does speak a couple of lines later of "definite truth" (85.15). But at the very least, (A) receives support from the fact that he does not immediately or explicitly say that we need to understand "definitely" as modifying the passage, as do the ancient commentators in similar contexts. ${ }^{33}$ Still worse for (B), at one point al-Fārābī comes to explain what it means for something to be definitely the case, but says only: "from the two [antitheses], the affirmation alone is true, to the exclusion of the negation (al-müjab min-humā huwa al-șädiq wahdahu, dūna al-salb)" "34. On interpretation (B), this would describe the indefinitely true affirmation no less than the definitely true affirmation.

Thus the prima facie case for interpreting the first solution in accordance with (A) is very strong, simply to judge from the way al-Fārābi speaks of the indefinitely true and false. We have still to consider several more complicated philosophical issues relative to this first solution. First, we have the following rather puzzling passage, regarding the final lemma of ch. 9:

Commentary 97.7-15: [Aristotle] sets down the truth of the antitheses regarding any type of thing as being in accordance with its existence. For that whose existence is definite, the truth of the antitheses regarding it is definite. But for that whose existence is indefinite, the truth of the antitheses regarding it is indefinite. For each of the types of necessary things, the truth of the antitheses regarding it is definite. But for each of the types of possible things, the truth of the antitheses regarding it is indefinite. However, in the case of the equally possible [the truth] is completely indefinite ( $\hat{\imath}^{\prime}$ 'l-mumkin al-tasāwì 'alā ghayr al-tahșill al-tāmm), and truth and falsehood are by chance. But in the case of the possible that happens more often ('ala' 'l-akthar), the truth of one of the antitheses regarding it is more appropriate $(a h r \bar{a})$ than its falsehood. But in the case of what happens less often, its falsehood is more appropriate than [its] truth. Likewise, opposed beliefs about the types of existing things are in the same state regarding truth and falsehood.

What al-Fārābī says here seems flatly incompatible with (B), because according to (B) there should be no "degree" of truth for an antithesis about the future: either it is true or it is false. He seems rather to imagine, especially in the case of the "equally possible", i.e. a fifty-fifty chance, precisely what (A) suggests, which is that truth is not yet assigned exclusively to either antithesis, and will be assigned as chance will have it. The passage is compatible with (A) but seems to add something, namely the concept of a "more appropriate" truth.

33 E.g. Ammonius / Boethius 1998, 104, 158; Stephanus 2000, 156.

$34 \mathrm{He}$ explains the definitely true in a similar way at Treatise 79. 
What does al-Fārābī mean here? He has already told us that "we must understand 'more often ( $f i$ 'l-akthar)' to mean 'more of the time' or 'in more of the subject matter (mawdü al-shay')"' (95.6-7). ${ }^{35}$ This is problematic, since the examples of antitheses regarding future contingents that are given by al-Fārābī, like those given by Aristotle, all seem to refer to particular events, which happen only once (the particular sea battle, the particular cloak that may or may not be cut up). Al-Fārābī's most prominent example, which is introduced in the course of the second solution, is "Zayd will make a trip tomorrow". But Zayd can only make a trip tomorrow once, he cannot do it "more often" than not. What al-Fārābi must mean is that a statement about a future contingent may predict a particular instance of something that happens in general, though it need not. Thus, if tomorrow is Thursday, and Zayd goes to the marketplace almost every Thursday, then the truth of the statement "Zayd will make a trip tomorrow" is "more appropriate" than its falsity. Still, it is "indefinite" that Zayd make the trip, because he could still stay home, so (according to interpretation (A) at least), it is not yet true that Zayd will make the trip tomorrow. Thus al-Fārābi uses the phrase "completely indefinite" to describe the fifty-fifty chance: he has in mind a continuum between the "completely definite", which is a statement that is simply true, because it predicts something that will occur necessarily, and the "completely indefinite", which is just as likely not to occur as to occur. I see no way that interpretation (B) could accommodate this passage. For we can make some sort of sense of a truth that is not yet assigned being called "more appropriate" to one antithesis, insofar as that antithesis is more likely to turn out true. But it makes no sense for such an antithesis to be "more appropriately true" because it refers to something that is closer to being necessary than being contingent ${ }^{36}$.

35 The long passage just cited refers back to the lemma here explicated, which is $D e$ int 19a18-27, with the phrase ahrā wa akthar, "more appropriate and more often", at 94.16 in the Arabic version of the lemma.

36 The line of thought I am here ascribing to al-Fārābi needs to be distinguished from a possible third interpretation of "indefinite" truth, which has been put forward in an unpublished paper by Robert Sharples ("Ammonius and the Sea Battle: Standard and Non-Standard Interpretations"). Sharples proposes that Ammonius held a view, which he calls the "Intermediate Interpretation", distinct from (A) and (B). According to the Intermediate Interpretation, a statement is indefinitely true insofar as it now looks likely to turn out true - or because if things go on as they are now, it will turn out true. Sharples points out that the ancient commentators speak of truths as being "variable" over time, so that the statement "there will be a sea battle tomorrow" might be "indefinitely true" now, 
Two final considerations in favor of (A) emerge from considering the relation of the first solution to the second solution, to which we will presently turn. One consideration is that the first solution must be distinct from the second solution. For al-Fārābī explicitly introduces the problem of divine foreknowledge as one that the first solution cannot resolve, and the second solution as the answer to the new difficulty. But, as I will explain below, the second solution is the solution that interpretation (B) would ascribe to Aristotle. Instead al-Fārābī explicitly presents it as an alternative to Aristotle's solution. Therefore the correct interpretation of Aristotle, according to al-Fārābī, must be distinct from (B).

A second consideration is the presentation of the problem of divine foreknowledge itself. This begins with the following passage, which comes on the heels of a restatement of the first solution at the end of the commentary proper on ch. 9:

Commentary 97.27-98.5: If this is the case then someone might ask about God's knowledge of one of the antitheses regarding possibles: is it comprehended by [His knowledge] (hal huwa muhit bi-hì)? If so, then what will be the state of the truth of one of the antitheses for Him? Is its truth for Him, in accordance with His knowledge of it (bi-hasab ilmihi bi-hì), definite or not? If this is not definite for Him, then it will lack definiteness for Him just as it does for us. Then God would not know, regarding future possibles, which of the antitheses will come about (yahșulu: same root as tahșill), the affirmative or negative. So these things will be unknown for God, and God will not know things before their occurrence (kawn). ${ }^{37}$

It is easy to see why this would pose an additional problem not yet solved by Aristotle, if Aristotle is correctly interpreted by (A): since future contingents are indefinite not only to us, but in themselves, they are unknowable in principle or "by nature" (as al-Fārābī has just said at 97.20). This is because statements concerning them are, in themselves, as yet neither true nor false (or individually either-true-or-false). They are unknown because there is, as yet, nothing to know. But then God cannot know them either. He would only know them if they were "defi-

because the generals are already sending the ships into the battle zone, but "indefinitely false" an hour from now, because a peace treaty has been signed. This cannot be what al-Fārābi means, for two reasons. First, he does not anywhere speak of the truth values as being changeable over time. Second, if this were what he meant by "indefinitely true" it would make no sense to speak of a fifty-fifty chance as being "completely indefinite".

37 For the sake of readability I have not included the honorific phrases (e.g. "the mighty and exalted") that follow each mention of God in the text. 
nite", that is, if there were already a true statement about the future contingent whose truth He could grasp.

For (B), on the other hand, this passage is problematic. There seems no reason God couldn't know the truth of a true statement about the future, simply because the event to which it refers will occur contingently. One way for (B) to make sense of the passage is to lean heavily on the need for God to know with certainty that, e.g., Zayd will make the journey. Perhaps he supposes that certain knowledge, especially divine knowledge, must have something necessary as its object. But if that is what al-Fārābī means, he falls well short of making his meaning clear here; rather, he seems to think divine ignorance follows immediately and obviously from the claim that statements about future contingents are intrinsically indefinite. A more promising line of argument for (B) would be to suggest that God must necessarily know what He knows (hence, perhaps, the talk of God's needing to know things "definitely"). This would have the virtue of explaining why divine foreknowledge presents an additional problem to those canvassed in De int 9 itself. Suppose that God necessarily knows that a statement $P$ about a future contingent is true. It might be thought to follow that $P$ is now not just true, but necessarily true. And that, on (B), is precisely what Aristotle is trying to avoid. Unfortunately for (B) this interpretation too has an Achilles heel: as will become clear below, the solution al-Fārābi will go on to give would be vitiated by the assumption that $P$ is now necessarily true.

It seems abundantly clear, then, that interpretation (A) is the correct reading of al-Fārābì's first solution, the solution he finds in Aristotle. Now let us turn to the second.

\section{The Second Solution: Two Types of Necessity}

After he has introduced the problem of divine foreknowledge, al-Fārābi explains how troubling it would be, were the problem to remain unsolved. We cannot simply say that God is ignorant of future events:

Commentary 98.5-10: This is repugnant and unacceptable. All religions claim otherwise, and it seems very harmful for people to believe this. But if so, and if God knows the truth of one of the antitheses definitely, then indefiniteness ('adam al-tahsiil) is not in the very nature of the thing. Then our ignorance of it would not be caused by the nature of the thing, but by a deficiency in our own nature. And if this is the case, then the truth of one of the two antitheses is definite in itself ( $f \grave{i}$ dhātihi $)$, but we don't know it. So it would be just like the indefiniteness, for us, of necessary matters of which we are ignorant.

In contrast with the original sea battle problem as al-Fārābì understands it, the problem of divine foreknowledge is here set out as a genuine dilemma. The argument would force us to choose between deter- 
minism and the belief in divine foreknowledge, in a way that al-Fārābi believes we were not forced in De int 9 to choose between determinism and the denial of PB. Reasonably enough, al-Fārābī is of the view that we do not have immediate intuitive certainty that God knows the future, the way we do that some things are contingent. We will return to this point below.

Al-Fārābi considers two ways of dealing with the problem, both of which (again, in contrast to his treatment of the deterministic argument in De int 9) seek to avoid being caught on either horn of the dilemma. The first, unsuccessful attempt, is described as follows:

Commentary 98.21-24: Some people answer that God knows every existent in the way it exists (bi-hasab wujüdihì). So He knows the necessary necessarily, and the possible possibly, and He knows antitheses regarding necessity according to what they are about, and antitheses regarding possibility according to what they are about.

As Zimmermann has remarked, this solution probably has its ultimate basis in the work of Alexander of Aphrodisias, who says in De fato that "since to have foreknowledge of the things that are going to be is to have cognizance of them as being such as they are (for having foreknowledge is different from bringing about), it is clear that he who has foreknowledge of things that are contingent will have foreknowledge of them as such (hôs toionta)" 38 . This is a promising answer, but al-Fārābī dismisses it, as Zimmermann says, with a "snort of contempt" 39 :

Commentary 98.24-28: In their answer, they do not add anything more than this. Upon my life, this answer will satisfy only a questioner who is content with ignorance! If it is examined a bit more closely, it does not [follow] from this answer that God does not know the truth of one of the antitheses definitely, if what He knows, in accordance with (bi-hasab) the existence of the possible, is not that the truth of one of the antitheses regarding it is true definitely. ${ }^{40}$ Giving this answer amounts to admitting that God does not know the possible before its occurrence.

It is clear that al-Fārābi thinks that the suggested response is mere verbiage; but verbiage of what sort? The passage is not particularly

38 Translation and Greek text in Sharples 1983; this is Sharples' translation, at 81 (201.13-15 in the Greek). Cf. Zimmermann 1981, lxxxvi, note 1.

39 Zimmermann 1981, xcv; in note 2 on this page he interprets al-Fārābī's understanding of the Alexandrian solution roughly as I do in what follows.

40 This difficult sentence requires numerous textual emendations, and al-Fārābīs generous use of negations does not make it easier to follow his train of thought. As usual I have followed the readings suggested by Zimmermann. 
clear, but the last sentence tells us that he thinks the solution would simply grasp one horn of the dilemma, and admit that God is ignorant of future events. In light of this, it would seem that al-Fārābī understands the answer ("God knows the possible possibly") to mean "God knows that $P$ is possibly true". But, given the resources of the first solution, this is what even humans know about the possible: that it may occur or not. So we are thrown back on the claim that such statements are, for God, indefinite, meaning that neither antithesis is true to the exclusion of the other.

In what follows al-Fārābì presents a solution that he finds much preferable. Ironically, this solution is not unlike what Alexander was in fact proposing. Here is his opening attempt to explain the solution:

Commentary 99.1-8: The right answer is to say that something's following from something else necessarily is not the same as the thing that follows being necessary in itself. For, from the truth of the affirmative statement, there does follow the necessity of the thing's existence. But from this it does not follow that the thing necessarily exists in itself. Rather, its following from the truth of the statement is necessary. A thing may follow from something else necessarily, but not be necessary in itself. For example, conclusions that are possible in themselves follow necessarily from the syllogisms that lead to them, without those conclusions that follow necessarily being necessary in themselves. For their possibility is not removed by the necessity of their following from the premises.

What al-Fārābi is suggesting, in a rather labored fashion, is this. Suppose that the statement "there will be a sea battle tomorrow" is now true. Though it does follow necessarily from this that there will be a sea battle, still the sea battle is not intrinsically necessary, but contingent. His comparison to the syllogism is helpful: from premises that are contingently true a contingently true conclusion necessarily follows. ${ }^{41}$ Al-Fārābi goes on to make this yet clearer with the aforementioned example of Zayd's making a trip tomorrow. If I say now truly that Zayd will make the trip, it follows from this that he will do so; yet still "there is in Zayd the possibility that he stay home. The only necessity involved is the necessity that his leaving his house follows from the true statement. But if we grant that Zayd is capable ( $q \bar{a}$ dir) of staying home or of making the trip, then these two antithetical outcomes are equally possible" (99.13-15). This distinction between two kinds of necessity allows him to solve the problem of divine foreknowledge by saying that although God knows that the statement "Zayd will make the trip" is true,

41 On this analogy see Gyeke 1977, 35. 
this is compatible with Zayd's having the possibility or "capability" to stay at home. ${ }^{42}$

There are several things worth noting about this solution, which as far as we can tell is being put forward by al-Fārābī as his own invention. First, al-Fārābī's point will work just as well against the original sea battle problem as it does against the dilemma of divine foreknowledge. ${ }^{43}$ This is why I have referred to it as al-Fārābī's "second solution" to the problem presented in De int 9, even though al-Fārābi thinks it is not the one Aristotle had in mind. If ascribed to Aristotle the solution would yield a version of interpretation (B), and a different analysis of Aristotle's argument. For according to what al-Fārābī has said here, as on (B), statements about future contingents may be true (only true, and not either-true-or-false) without the event they predict being necessary. Like interpreters who put forward a version of (B) as a reading of Aristotle's own view, al-Fārābī additionally provides an explanation of where the deterministic argument goes wrong. Suppose that $P$ is the proposition "it is true at $t_{1}$ that Zayd will travel at a future time $t_{2}$ ", and $Q$ the proposition "it is true at $t_{2}$ that Zayd travels". Then the determinist fallaciously assumes that Nec (If $P$ then $Q$ ), which is true, is tantamount to or implies If $P$ then Nec $Q$, which is false. ${ }^{44}$ It is false because the truth of a present statement about Zayd's journey does not exclude the possibility of Zayd's staying at home: it just excludes that this possibility will be realized.

42 The use of the word qa adir here, along with some of the rhetoric used at the outset of this section (if determinism were true, "the punishment meted out to man in this world or in the hereafter will not be the result of things that occurred by his volition or choice”, Commentary 98.16-17), confirms that al-Fārābì is again responding to debates within contemporary kalām.

43 Note that, as I remarked above, the second solution would not work against the claim that what God knows is necessarily true, because God necessarily knows it. Then the occurrence of Zayd's journey would be like the conclusion of a syllogism with necessary premises, rather than of a syllogism with contingently true premises.

44 Contrast this to an alternative diagnosis mentioned above, that the determinist confuses the unobjectionable Nec (P or Not-P) with Nec P or Nec Not-P. Al-Fārābi prefers to speak of the thing (e.g. the journey, the sea battle) as being necessary or possible "in itself", rather than of statements or propositions about the thing being necessarily or contingently true. But it is hard to express the fallacy in these terms, so I have taken the journey's necessary existence as being equivalent to the necessary truth of a timeless proposition about the journey. I hope though that this way of putting it still captures al-Fārābī's essential point. 
This brings us to another important point about the second solution: it commits al-Fārābi to the notion of unactualized possibilities. What is more, al-Fārābi knows it. He says that if we adopt the second solution, we will have to admit that "there may be something that is eternal and that has always existed, but that possibly does not exist or is possibly corrupted, and that could even have failed to exist previously" (Commentary 99.26-27). He compares this to the claim that it is possible for God to commit injustice, though He never does. ${ }^{45}$ The Greek sources for his discussion here are unclear. Al-Fārābī ascribes the view to Plato (Aflātun), but Zimmermann suspects that he may have known a garbled reference to the ancient dispute between Philo and Diodorus Cronus over the proper understanding of modality. ${ }^{46}$ Certainly he knows that there was a debate over unactualized possibilities in the ancient world; he says at one point that the non-existence of what never happens "is necessary from one point of view and possible from another" (Commentary 100.3-4). But it may be that the reference to Plato is accurate; it could refer to the Timaeus $(41 \mathrm{~b}-\mathrm{c}){ }^{47}$

In any case, we here see al-Fārābi finding his way from the classical, Aristotelian model of modality, which has been called the "statistical model", towards what in the Arabic tradition is a new modal theory. The statistical model of modality holds that the possible is what exists sometimes, the necessary is what always exists, and the impossible is what never exists. This conception has been ascribed to Aristotle by modern scholars, ${ }^{48}$ and it appears in the Arabic tradition both earlier and later than alFārābi ${ }^{49}$ The new theory is that possibility, necessity and impossibility are intrinsic to a thing and depend on its nature. A thing may be intrinsically possible and yet always fail to exist, and a thing may always exist without being intrinsically necessary: in short, there are possible counterfactuals. ${ }^{50}$ This theory will be used to great effect by Ibn Sinnā (Avicenna), who famously distinguishes between the "necessary-initself" and the "necessary-through-another" that is only possible in itself. Al-Fārābỉ's discussion of the difference between the two kinds of necessity in the present context anticipates Ibn Sīnā. ${ }^{51}$

45 As noted by Zimmermann 1981, cxvii, this was a position held by the early $m u$ takallim Abū 'l-Hudhayl.

46 For Philo's position and the controversy in general see Bobzien 1998, 108-111.

47 My thanks to Taneli Kukkonen for this suggestion.

48 Especially in the early work of J. Hintikka, who even argued that De int 9 could be understood as motivated by problems deriving from the statistical model; see Hintikka 1973. However Hintikka later moved away from this reading.

49 The Book of Definitions ascribed to al-Kindi has definitions of "possible", "necessary" and "impossible" that set out the statistical model (see Adamson 2002 , 266f.). For the statistical model in post-Avicennan Arabic thought see Kukkonen 2000a and 2000b.

50 The point is also stressed at Baffioni / de Vincentis 1981, 66.

51 Wisnovsky 2003, 219-225, also sees this section of al-Fārābī's commentary as an important precursor of Avicenna. Wisnovsky's brief, but excellent, discussion of the text points out that al-Fārābi stops short of fully endorsing the idea of something being "possible of existence in itself", possibly because this could imply that such a thing could exist independently of being caused. I would add that al- 
Given the philosophical and historical importance of al-Fārābī's "second solution", it is somewhat astonishing to discover that al-Fārābi himself seems unconvinced of its value. This is clear from the way that al-Fārābi frames the solution. As already noted above, he sets out the divine foreknowledge problem as a genuine dilemma. As we should expect, given his earlier remarks about freedom, if we are forced to choose between divine foreknowledge and contingency, then so much the worse for divine foreknowledge. The only way he can see to save this foreknowledge is to give the solution just described, and accept the attending conception of modality. But al-Fārābī is strikingly hesitant here. He reiterates that "this is something that philosophers in antiquity disagreed about" (Commentary 100.19), and at the end simply concludes that the Philonic, non-statistical understanding of modality is an "opinion ( $\left.r a^{3} y\right)$ [that is] more useful $\left(a n f a^{c}\right)$ in religions than the other opinion". This none-too-ringing endorsement echoes language al-Fārâbi used in setting up the dilemma: the rejection of foreknowledge in God "is repugnant and reprehensible to all religions and very, very harmful for people to believe" (Commentary 98.18-19).

Readers familiar with the Farabian corpus will recognize in these passages al-Fārābī's notoriously condescending attitude towards beliefs adopted within the religious sphere, as contrasted to the demonstrative scientific knowledge that is embodied by philosophy. But even without this context it is clear that al-Fārābi stops short of fully endorsing his second solution. The question is why. Of course one possible explanation is that he is reluctant to disagree with Aristotle as understood by the commentators. On al-Fārābī's understanding, they say that for Aristotle present statements about future contingents are not definitely true or false, in the sense that interpretation (A) would give to this phrase. ${ }^{52}$ The clash between the authority of Aristotle and the commen-

Fārābī does not seem to have left behind the Aristotelian notion that the present and past are "necessary", whereas on the new, Avicennan understanding of modality, even what already obtains and is necessary-through-another remains merely possible-in-itself.

52 If he were to adopt the second solution as an interpretation of Aristotle, rather than just a way of escaping from the problem of divine foreknowledge, al-Fārābi would be forced to rethink his entire analysis of De int 9 . The step that infers future necessity from present truth - which, as we saw, al-Fārābi calls "self-evidently correct" in his commentary - would on the second solution be identified as the fallacious move in the determinist's argument. The argument as a whole would be seen as sophistical, rather than as a valid argument that proceeds from a bad premise. 
tators on the one hand, and a debatable modal theory on the other, may have seemed to al-Fārābì an uneven contest. But I suspect that al-Fārābi’s diffidence has a simpler explanation: he does not really believe that God knows truths about future contingents. Indeed, he probably does not believe that God knows truths about particulars at all, whether past, present or future, at least not qua particulars..$^{53}$ If this is right, then the whole discussion of divine foreknowledge is motivated by an erroneous claim, which is that present statements about future contingents must be exclusively true or false because God knows that they are true or false. This is suggested by his repeated claim that the denial of foreknowledge is "very harmful" - harmful, but not necessarily false. If this is al-Fārābī's attitude then in fact he is not (at least in this respect) following the commentators, because he knows that the ancients too worried about the problem of God's foreknowledge - as witnessed by his dim awareness of Alexander's solution. ${ }^{54}$ The combination of ancient and contemporary concern seems to have been sufficient to induce alFārābì to explain how God could know future contingents, if indeed $\mathrm{He}$ does. But his real interest is to explain Aristotle's intentions in De int 9 , and this is what he believes he has already done with the first solution..$^{55}$

Adamson, P. 2002. "Abū Ma shar, al-Kindī and the Philosophical Defense of Astrology". Recherches de Théologie et Philosophie médiévales 69: 245-270.

-. 2003. "Al-Kindī and the Mu tazila: Divine Attributes, Creation and Freedom". Arabic Sciences and Philosophy 13: 45-77.

Ammonius / Boethius 1998. On Aristotle On Interpretation 9, transl. D. Blank and N. Kretzmann. London.

Anscombe, G.E.M. 1956. "Aristotle and the Sea Battle: De Interpretatione Chapter IX". Mind 65: 1-15.

Bäck, A. 1992. "Sailing Through the Sea Battle". Ancient Philosophy 12: 133-151.

Baffioni, C. / Nasti de Vincentis, M. 1981. Il cap. 9 del De interpretatione di Aristotele nel commentario di al-Fārābī. Naples.

53 Cf. Avicenna's well-known discussion of this in the Metaphysics of the Healing, VIII.6: Ibn Sīnā 1960, 355-362.

54 As Zimmermann 1981, lxxxvi, remarks, this issue arises in the Alexander archetype represented by Boethius. Ammonius, Stephanus and the anonymous commentary also discuss divine foreknowledge; see Ammonius $80.8 \mathrm{ff}$., Stephanus 2000, 154f., and Tarán 1978, 55.6ff.

55 I am grateful to audiences at King's College London, the University of Liverpool, and Cambridge University for helpful comments on this paper; Stephen Menn and Taneli Kukkonen were kind enough to read an earlier draft of the paper and both gave me numerous helpful suggestions and criticisms. 
Black, D. 1991. "Aristotle's Peri hermeneias in Medieval Latin and Arabic Philosophy". In Aristotle and his Medieval Interpreters, ed. R. Bosley and M. Tweedale. Calgary: 25-83.

Bobzien, S. 1998. Determinism and Freedom in Stoic Philosophy. Oxford.

Boethius 1877. Commentarii in librum Aristotelis Peri Hermêneias, ed. C. Meiser. Leipzig.

Druart, T.-A. 1981. "Al-Fārābī’s Causation of the Heavenly Bodies". In Islamic Philosophy and Mysticism, ed. P. Morewedge. Delmar: 35-45.

Ehrig-Eggert, C. 1989. "Yahyā ibn 'Adī: Über den Nachweis der Natur des Möglichen". Zeitschrift für Geschichte der arabisch-islamischen Wissenschaften 5: 283-297 [Arabic text 63-97].

-. 1990. Die Abhandlung über den Nachweis der Natur des Möglichen von Yahyā ibn 'Adì (gest. 974 A.D.). Frankfurt am Main.

Al-Fārābī 1926. Al-Taḥ̣ìl al-sacāada. Hyderabad.

Frede, D. 1985. "The Sea-Battle Reconsidered: A Defence of the Traditional Interpretation". Oxford Studies in Ancient Philosophy 3: 31-87.

Gaskin, R. 1995. The Sea Battle and the Master Argument. Berlin.

Gyeke, K. 1977. "Al-Fārābī of [sic] the Problem of Future Contingents". Second Order 6: 31-54.

Hintikka, J. 1973. "The Once and Future Sea Fight: Aristotle's Discussion of Future Contingents in De interpretatione 9". In Hintikka, J., Time and Necessity. Oxford. $147-178$.

Ibn Sīnā 1960. Al-Shifă’': al-Ilāhiyyāt, volume 2, ed. M.Y. Moussa, S. Dunya, and S. Zayed. Cairo.

Ivry, A. L. 1984. "Destiny Revisited: Avicenna's Concept of Determinism”. In Islamic Theology and Philosophy, ed. M. E. Marmura. Albany: 160-171.

Kogan, B. S. 1985. "Some Reflections on the Problem of future Contingency in Alfarabi, Avicenna and Averroes". In Divine Omniscience and Omnipotence in Medieval Philosophy, ed. T. Rudavsky. Dordrecht: 95-101.

Kukkonen, T. 2000a. "Possible Worlds in the Tahäfut al-Tahäfut: Averroes on Plenitude and Possibility". Journal of the History of Philosophy 38: 329-348.

-. 2000b. "Possible Worlds in the Tahâfut al-Falāsifa: al-Ghazālī on Creation and Contingency". Journal of the History of Philosophy 38: 479-502.

Kutsch, W. / Marrow, S. (eds.) 1960. Alfarabi's Commentary on Aristotle's Peri Hermêneias. Beirut.

Küyel-Türker, M. 1966. "Kitāb bārī armīniyās ay al- 'ibāra". Arastīrma 4: 1-85.

Mahdi, M. 1962 [repr. 2001]. Alfarabi: Philosophy of Plato and Aristotle. Ithaca.

Marmura, M. E. 1985. "Divine Omniscence and Future Contingents in Alfarabi and Avicenna". In Divine Omniscience and Omnipotence in Medieval Philosophy, ed. T. Rudavsky. Dordrecht: 81-94.

Moravcsik, J. 1968. Aristotle: A Collection of Critical Essays. London.

Rescher, N. 1963. "An Interpretation of Aristotle's Doctrine of Future Contingency and Excluded Middle". In Rescher, N., Studies in the History of Arabic Logic. Pittsburgh: 43-54.

Schwartz, M. 1967. "The Letter of al-Hasan al-Basrī”. Oriens 20: 15-30. 
Seel, G. (ed.). 2001. Ammonius and the Seabattle: Texts, Commentary and Essays. Berlin.

Sharples, R. W. 1982. "An Ancient Dialogue on Possibility: Alexander of Aphrodisias Quaestio 1.4". Archiv für Geschichte der Philosophie 64: 23-38.

-. 1983. Alexander of Aphrodisias on Fate. London.

Sorabji, R. 1980. Necessity, Cause and Blame. London.

Stephanus 2000. On Aristotle On Interpretation, transl. W. Charlton. London.

Talanga, J. 1986. [Review of Zimmermann 1981]. Archiv für Geschichte der Philosophie 68: 302-309.

Tarán, L. 1978. Anonymous Commentary on Aristotle's De Interpretatione. Meisenheim.

Waterlow, S. 1982. Passage and Possibility: A Study of Aristotle's Modal Concepts. Oxford.

Wisnovsky, R. 2003. Avicenna's Metaphysics in Context. London.

Zaroug, A. H. 1972. "The Concept of Possibility in Some Arabic Commentaries on Aristotle's De Interpretatione". Unpublished University of London $\mathrm{PhD}$ thesis.

Zimmermann, F. W. 1981. Al-Fārābī's Commentary and Short Treatise on Aristotle's De Interpretatione. Oxford. 